\title{
Decentralisation when Land and Resource Rights are Deeply Contested: A Case Study of the Mkambati Eco-Tourism Project on the Wild Coast of South Africa
}

\section{BEN COUSINS and THEMBELA KEPE}

\section{INTRODUCTION}

This contribution examines a failed community-based eco-tourism development project in one of the poorest rural regions of South Africa - the Wild Coast of the Eastern Cape Province. In the Mkambati project, both local and non-local actors and agencies have been involved in a complex politics of land and natural resource rights, and the question of 'who decides' (and therefore 'who benefits') has been central to the many-sided conflicts that have erupted.

The project is located within the former Transkei 'homeland' of South Africa, one of several targeted for high profile Spatial Development Initiatives (SDIs). The SDI concept involves 'targeted interventions by central government for helping unlock economic potential and facilitate new investment and job creation in a localised area or region' [Jourdan, 1998: 718]. These interventions take the form of infrastructure development, mostly in spatially concentrated corridors or nodes and implemented through privatepublic partnerships, and the promotion of 'anchor projects' such as industrial plants, roads or resorts. A poorly defined version of decentralisation of decision making to the local level is a central feature of the SDI model in two respects: 1) the 'empowerment' of local communities (and local entrepreneurs), and 2) government facilitation of 'partnerships' between private-sector investors and local communities.

In South Africa the distinction between 'decentralisation' and 'privatisation' is currently somewhat blurred, given the dominance of neoliberal approaches to economic policy making. This case may resonate with experiences elsewhere, as multilateral agencies and donors increase pressure on governments everywhere to promote foreign investment, privatise service

Ben Cousins is Director and Thembela Kepe is a Researcher in the Programme for Land and Agrarian Studies, School of Government, University of the Western Cape. The authors would like to thank Anne Larson, Jesse Ribot and two anonymous reviewers for their incisive comments on a first version of this essay.

European Journal of Development Research, Vol.16, No.1, Spring 2004, pp.41-54 
delivery and thus to 'outsource development' in the name of market efficiencies.

The reasons for the failure of the eco-tourism project in Mkambati are many and various [Kepe et al., 2001; Kepe, 2001], but include some that speak directly to debates on democratic decentralisation, as well as debates regarding the beneficiaries of eco-tourism projects. ${ }^{1}$ Democratic decentralisation grants important decision-making powers to downwardly accountable local actors [Ribot, 2001]. Yet for the SDI project, the devolution of effective decisionmaking powers from central bodies to local actors was not seen as a key issue and was barely addressed, and a rhetoric of 'empowerment' has been employed in its place. Also ignored was the question of the accountability of various local bodies to the community members whose interests they have claimed to represent. Even for local residents, democratisation and accountability were not articulated as key issues. The emphasis on privatesector partnerships and local entrepreneurship within the SDI, as if it were a form of (or substitute for?) decentralisation, fostered the attempted capture of the development project by entrepreneurial elites, which then generated resentment among and fierce resistance by other community members.

One of the key goals of democratic decentralisation is to promote and institutionalise local participation, and hence to operate from a clear understanding of local needs and desires [Ribot, 2001]. Nevertheless, SDI project planning and attempts to establish its local institutional framework barely even recognised the subtle realities of the use of natural resources in local livelihood strategies, or the local institutional arrangements through which access to resources is gained. Yet these were central to the actions and motivations of local residents. At the same time, national and provincial government departments that played a key supportive role in the SDI by implementing land-reform policies, securing land and resource rights, and resolving deep-rooted tenure disputes accorded these a low priority. In cases such as these, however, it is clear not only that powers should be devolved to downwardly accountable local actors but also that the devolution of powers must be accompanied by effective tenure reforms. These reforms must clarify each actor's rights as well as strengthen their capacity to exercise them.

Finally, the case evidence supports the argument that effective democratic decentralisation requires a strong central state that is committed to the process, provides adequate resources for the devolution of decision-making powers and facilitates the creation of downwardly accountable local bodies.

\section{POLICY FRAMEWORKS}

Understanding the local power dynamics in Mkambati is difficult without situating them within the national policies developed and implemented since 
1994 by the post-apartheid government. These generally assert that there is an important role for local decision-making (often by 'communities'), and notions of 'participation' and 'consultation' are common in policy documents such as White Papers. However, the locus of decision-making powers and mechanisms to ensure the accountability of decision makers are much less-clearly articulated.

\section{Spatial Development Initiatives (SDIs)}

From their inception in the mid 1990s, SDIs were seen as integral to the new government's macroeconomic strategy. Within this, a 'paradigm shift' in economic policy towards international competitiveness, regional co-operation and diversified ownership were emphasised [Jourdan et al. 1996], thereby addressing the spatial distortions of apartheid, a 'fast-track and integrated approach' from within government, and the pivotal role of the private sector [Platzky, 2000]. The latter in particular clearly aligns the SDI concept with neo-liberal development doctrine [Rogerson and Crush, 2001].

The SDIs are premised on the need to attract investment capital to previously neglected areas. Objectives include sustainable job creation, growth and development configured to suit a locality's inherent development potential, the mobilisation of private sector investment and lending, 'economic empowerment' through small, medium and micro-enterprise (SMMEs), and exploitation of under-utilised local resources as the basis for industrial and export-oriented growth [Kepe et al., 2001; Rogerson and Crush, 2001].

A number of SDIs are being implemented within the wider Southern Africa region. Thirteen SDIs in different parts of South Africa had been initiated by late 2000. On the Wild Coast of the former Transkei, several development 'nodes' were identified - with the focus on eco-tourism. The existence of five nature reserves, together with the scenic beauty of the coastal zone, is seen to provide a basis for the expansion of both national and international tourism, and a new Pondoland National Park is being planned. Several development nodes have been identified, including Dwesa/Cwebe/Nqabara, Coffee Bay/Hole-in-the-Wall, Port St Johns, Magwa and Mkambati. The aim is to establish eco-tourism ventures in these anchor project sites, with the hope that improvements in infrastructure and other investments will encourage a range of economic initiatives in the surrounding areas. It is hoped that the five nature reserves found along the coast together with scenic areas such as Hole-in-theWall, will attract both national and international tourists to the Wild Coast. Agriculture and forestry have also been identified as enterprises with development potential, and government planners estimate that in the Eastern Cape around 120,000 hectares of land could be afforested, mostly in the communal areas of the Wild Coast. Private companies are encouraged to enter into agreements with communities in these areas. 
In South Africa the notion of 'empowerment' refers to increasing the level of participation in the mainstream economy by black South Africans. In the SDIs this is supposed to take place through:

- Community control over land;

- Community involvement in the management of productive assets;

- Community-held equity shares in new enterprises; and

- Support for SMME development.

A critical issue for the SDIs is the extent to which these features are compatible with significant levels of private investment, and the need for public agencies to facilitate 'partnerships' between communities and investors. Increasingly, district councils and local municipalities are being seen as the levels of government that should play this role. Here, decentralisation is explicitly allied with neo-liberal conceptions of market-driven development. Not at all clear in the SDI model is the institutional location of decision-making power at local or 'community' level.

\section{Local Government Reform}

Following the advent of majority rule in 1994, a transitional local government regime was installed until such a time as the details of a more permanent system could be put into place. Problems experienced in the 1995-2000 period included a lack of experience and skills among elected councillors, inadequate mechanisms for effective consultation with and feedback to constituents, inadequate financial resources, weak decision-making powers and a lack of accountability mechanisms [Manor, 2000].

Following new legislation and a second round of elections in 2000, a permanent new system of local government has replaced the transitional arrangements. The number of district councils and primary level bodies has been reduced from 843 to 299 , consequently leading to a greatly increased 'distance' between elected representatives and constituents. This, together with a proportional representation system and selection of candidates from party lists, makes accountability to those constituents more difficult. Local government is required to be developmental, and all municipalities must produce Integrated Development Plans. These Plans must provide for extensive public participation in the planning process. Yet municipalities in the poverty-stricken former 'homelands' have a small or non-existent revenue base, meaning that the problem of 'unfunded mandates' [Manor, 2000] has been perpetuated if not exacerbated. Also unresolved in both the 'transitional' period and since 2000 is the issue of the roles and powers of traditional leaders in local government [Ntsebeza, 2001]. Partly because of serious capacity problems, SDIs have generally not attempted to work through - or even in cooperation with - local government bodies. 


\section{Land Reform}

The overarching goal of land reform in South Africa is to redress the racially based land dispossessions of the apartheid era and the resulting highly inequitable distribution of land ownership. Other goals include land-tenure security for all and the enabling of land-based economic development. The three main components of land reform are land redistribution, land restitution and tenure reform [Department of Land Affairs, 1997]. Restitution policy aims to restore land and provide other remedies (that is, alternative land or financial compensation) to people dispossessed by racially discriminatory legislation and practice. Policies and procedures are based on the Bill of Rights and the Restitution of Land Rights Act of 1994. A programme of land tenure reform has been slow to emerge [Cousins and Claassens, 2003].

The land-tenure system in the former 'homelands' is usually described as 'traditional' in character but, as elsewhere in Africa, chiefs and headmen formed an integral part of a colonial system of indirect rule in which customary law and communal land rights were administered by chiefs. The legacy of this history is that communal land is still owned by the state, and the land rights of the occupants are not well defined and protected by law. For most rural people, rights still take the form of permits. Land administration is currently in a state of chaos, and there is widespread confusion over who may make decisions on land in cases where development projects such as housing schemes are planned. Tensions and disputes over land rights are common. In response to increasing political pressure, government is currently drafting a Communal Land Rights Bill. ${ }^{2}$ Among other provisions, this will define the powers of local land administration bodies. A central issue is the accountability of such bodies to rights holders.

\section{THE CASE STUDY AREA AND LOCAL INSTITUTIONAL} FRAMEWORKS

The area known as 'Mkambati' is situated in north-eastern Pondoland $\left(31^{\circ} 13^{\prime}-31^{\circ} 20^{\prime} \mathrm{S}\right.$ and $\left.29^{\circ} 55^{\prime}-30^{\circ} 4^{\prime} \mathrm{E}\right)$, in the Eastern Cape Province, South Africa. It is inhabited by the mPondo people, who speak a Xhosa dialect (IsiMpondo). The case study focuses on three sub-areas within the wider Mkambati area that are under different tenure regimes: communal tenure settlements to the west; 11,000 hectares of state land in the centre, formerly used by a now defunct parastatal agricultural project (the Transkei Agricultural Development Corporation, or TRACOR); and the 7,000-hectare state-owned Mkambati Nature Reserve to the east. The communal tenure area comprises seven villages that make up the Thaweni Tribal Authority. Of these, Khanyayo is the village that has been at the centre of conflict over the Mkambati SDI. 
The inhabitants of the seven villages generate their livelihoods through a mixture of arable and livestock farming and the collection of a range of natural resources as well as various off-farm sources, including remittances and pensions. Access to natural resources is mediated by a variety of formal and informal institutions. These include national and provincial laws and regulations, official land and resource tenure regimes, embedded (but not officially recognised) systems of property rights, customary norms and practices around resource sharing, and illegal (but socially structured and locally legitimate) means of access. ${ }^{3}$

Of the seven villages within the Thaweni Tribal Authority, Khanyayo has the closest ties, in terms of both history and proximity of settlement, to the Mkambati Nature Reserve and the TRACOR state farm. In 1920 the Khanyayo people were forcibly removed from an area of about 18,000 hectares - which they used for settlement, livestock grazing and other resources - to make way for a leper colony. For over 70 years the Khanyayo have aggressively attempted to regain their land rights, and they have continued to hunt and harvest natural resources within the area that they lost - legitimising this use through the informal institution of ukujola (see note 3). Following the closure of the leper colony in 1976 and its conversion into the Mkambati Nature Reserve and TRACOR state farm, tension between the state and the Khanyayo increased, particularly over grazing rights. In 1997, following the official end of apartheid in 1994, the residents of Khanyayo lodged a claim against the state for restitution of their land.

Throughout the early 1990s, the Khanyayo had relied on moral support from the other six villages in their fight for their rights to the nature reserve land and the TRACOR state farm. Initially, this support was a result of common political affiliation, which at the time was unanimously in favour of the African National Congress (ANC). However, it was also during the early 1990s that the political landscape in Mkambati area began to blur due to strained relations between the traditional leadership (chiefs and headmen) and democratic political organisations. The traditional leadership was challenged by the rise of local civic organisations affiliated with the ANC. Former migrant workers who had returned to the villages established civic associations throughout the area, some as branches of the South African National Civic Organisation (SANCO). Control over land allocation was a major bone of contention.

In Khanyayo village, a civic organisation - the Khanyayo-Mkambati Development Forum (KMDF) - was formed by local political activists in 1996, mainly to spearhead the fight to regain their land rights. The formation of the KMDF was not welcomed by leaders in the other six villages, who tended to support the senior chief at the head of the Thaweni Tribal Authority - Chief Mhlanga. In 1992 the chief and his supporters (who were mainly from the wealthier and politically powerful elite) had formed an organisation known 
as the Joint Management Committee (JMC), supposedly in order to facilitate development in the Mkambati Nature Reserve. The JMC argued that all seven villages under the Thaweni Tribal Authority should be co-claimants to the land in question as they were all under a single chief.

By 1994 two members of the original JMC had taken political office - one in the national parliament and one in the local Transitional Representative Council. The JMC has continued to use these politicians as advisors, and they have assisted the JMC in securing the support of senior officials in the provincial government, including the premier, in their struggle to be seen as the only legitimate local institution within the Mkambati area.

Initially, the conflict over the land claim between the Khanyayo people, on the one hand, and the chief (together with the JMC), on the other, appeared to be a microcosm of countrywide conflicts between traditional authorities and democratic political structures [Ntsebeza, 1999]. However, in the Mkambati area the formally elected local government structures have not been major players in struggles over land and development. Between 1995 and 2000 a small number of councillors sat on the Transitional Representative Council of the nearby Lusikisiki municipality, but were not widely known to their constituents and were not very active in promoting local development.

This lack of a strong local presence by elected councillors has continued since the restructuring of local government in 2000. Mkambati now falls within the Ingquza Hill municipality, which is split into separate wards. Neither of the two current councillors reside in any of the villages involved in the disputes over land in Mkambati. The central government's continuing indecision regarding the roles and powers of traditional leaders contributes to ongoing uncertainty within Mkambati as to where real political and administrative authority at the local level resides.

Given this uncertainty, as well as the long-term conflict over land rights in Mkambati and TRACOR, any development targeting the disputed land could be expected to face numerous challenges. As it turned out, these issues did indeed plague the SDI project in Mkambati.

\section{THE SDI AND DEVELOPMENT POLITICS IN MKAMBATI}

\section{SDI Planning and Community 'Empowerment'}

In line with the SDI's goal of targeting areas that have both needs and economic potential, the Mkambati area was identified as one of the five 'development nodes' along the Wild Coast. ${ }^{4}$ The nature reserve was central to SDI plans for encouraging large-scale foreign investment in eco-tourism ventures in this node. Private investment would focus on the extension 
and upgrading of tourist facilities to cater to local and international tourists and sport hunters; the facilities would include accommodation for a total of 90 visitors. The government's contribution would be to improve infrastructure including roads, electricity and telephones - in the reserve area as well as in the communal-tenure settlements. Outside the nature reserve, forestry companies were encouraged to consider planting commercial forests in sections of TRACOR state land as well as in the surrounding communal areas. It was envisaged that local people would benefit from the SDI in a number of ways, such as employment, opportunities for local entrepreneurs and rental payments to the community by investors.

When the SDI began, the Department of Trade and Industry, together with the Eastern Cape provincial government, invited the private sector to submit proposals for investment in Mkambati and other development nodes on the Wild Coast. Among other things, private-sector proposals had to address a key principle of social empowerment established by government [Government of Eastern Cape, 1998]: the 'community' must benefit directly from the proposed developments in the short, medium and long term. Consultants suggested a number of models for community participation and empowerment in Mkambati, and government and SDI implementers focused on three [Koch et al., 1998].

The first empowerment model involved the private sector entering into a lease agreement or management contract to operate facilities developed by communities on communal land. Under this model, the community would remain responsible for the development and maintenance of infrastructure and facilities. The private sector would be responsible for environmental management and for facilitating SMME development and support. In this model, tourism remained under the private sector. Under the second model, the community that requested proposals from the private sector for partnerships would (with assistance from the state) develop, operate and maintain all required tourism facilities, and assume responsibility for environmental management and SMME development and support. The third model involved 'state-owned land'. Here the state would request private-sector proposals for all three functions - to develop, operate and maintain tourism, as well as environmental management and SMME development and support. The private sector would be instructed to build into the proposals options for facilitating community empowerment. This model required that communities adjacent to the state land be given the opportunity to purchase or access equity in the tourism operation. It was this model that was adopted in the Mkambati case, notwithstanding the restitution claim to the land within the nature reserve and the TRACOR estate.

The SDI implementing team for the Mkambati node comprised officials from the Development Bank of Southern Africa (DBSA) and the Department 
of Trade and Industry, as well as consultants employed by the provincial government. The empowerment model they adopted involved a clear role for a local organisation to represent 'community interests' in the form of a 'community-private sector partnership'. This body would connect the ecotourist project to local development planning processes, and actively facilitate projects to produce the spin-off benefits which they hoped would flow from external investment in upgraded tourist facilities in the nature reserve. To play this role, it should have powers to negotiate on behalf of the beneficiary community, distribute income from leases or other sources of revenue and oversee the allocation of employment in public works programmes such as roads.

In 1997 the SDI implementing team formed the Mkambati SDI Committee, which was to act as this link between the 'local community', the SDI team and investors. This committee was mainly composed of JMC members, who worked closely with the chief. This committee became locked in disputes with the KMDF, which represented Khanyayo villagers in the fight to regain land rights. Consequently, residents of Khanyayo village did not recognise the legitimacy of the SDI Committee. Uncertainty about institutional responsibilities, together with ongoing tensions between traditional authorities and elected local government in the area, hampered attempts to resolve disputes between the KMDF and the SDI Committee (or the JMC).

\section{The Politics of Land and Resource Rights in the Mkambati SDI}

The advent of the SDI soon after the lodging of a land restitution claim exacerbated the conflict between Khanyayo residents and leaders of the other six villages in the Mkambati area, but also brought new tensions and disputes of its own. Largely unresolved to date, these have effectively stalled the proposed SDI. Consequently, among other things, no eco-tourism development has taken place in the area, and by June 2003 the nature reserve was still operated by the provincial department responsible for conservation. We argue that in order to have any chance of success, the SDI project cannot proceed without first resolving land claims, and, second, building acceptable institutions for resolving local disputes.

A host of actors and interest groups has pursued a variety of competing objectives, and just who should be 'empowered' has been fiercely contested. The different groupings have engaged in a number of power plays and entered into complex and shifting relationships with each other at different moments in time, ranging from alliances or collaboration at one end of the spectrum, through wary neutrality or relative indifference, to outright hostility and confrontation at the other. Since 1990 the political terrain in Mkambati has become steadily more complex - and less stable. Three key issues are at the heart of the conflicts that have emerged. 


\section{1) Which 'community' is to be the beneficiary of the SDI?}

When the SDI was introduced, the 'Mkambati community' was an abstract concept, adequate perhaps for purposes of initial planning. The SDI's first definition of the 'local community' was based on geographical location [Kepe, 1999] and thus favoured the Khanyayo villagers, who are the immediate neighbours of Mkambati Nature Reserve. Members of the other six villages within the Thaweni Tribal Authority were unhappy with this and campaigned through the JMC for all six to be included within the definition of 'beneficiary community'. When the JMC (now composed mainly of the local business and political elite, including some in government posts) threatened violence, the SDI implementation team quickly yielded to their demands. This decision has contributed in great part to the ongoing tensions between Khanyayo villagers and people living in the other six villages. Lack of clarity on this fundamental issue persists, despite attempts to find a mediated solution to the centrally important and still unresolved problem of the land claim [Kepe, 2001].

\section{2) Who owns the land on which the SDI eco-tourism project was to be located?} The SDI, with its empowerment models that offered significant benefits for land-owning communities, seems to have intensified the conflict over land rights in Mkambati. The Khanyayo people appeared confident that, based on history, their land claim would succeed and they would be regarded as the land-owning community for the purposes of the SDI development. However, a year after the Khanyayo lodged their claim, the JMC followed with a counterclaim for the wider 'community'. The Restitution Commission was legally bound to treat both claims as potentially legitimate until proven otherwise, hence the Khanyayo and the JMC were to remain potential land owners of Mkambati Nature Reserve and TRACOR until the claim was resolved.

Concerned that the SDI project was being stalled by land disputes, the government commissioned several mediation processes between the warring factions. In 1999 mediation by facilitators on behalf of the provincial office of the Department of Land Affairs managed to get the JMC to withdraw its claim with the promise that they would be regarded as equal shareholders of any development taking place on the disputed land. While this did not please the Khanyayo, they appeared to agree to this compromise. However, with the land claim still unresolved by the beginning of 2003, tensions in the area have mounted and the SDI has ground to a complete halt.

\section{3) Which institution represents local people's interests?}

The question of which local body can claim to legitimately represent the interests of the 'local community' has been a central point of contention in the muddied waters of Mkambati's institutional landscape. Perhaps surprisingly, 
the main contenders have been neither local government bodies nor traditional leaders.

Local government bodies have been only peripherally involved in the struggles over land rights and SDI planning in Mkambati, perhaps because of their 'distance' from the local level and the fact that most ward councillors were not themselves residents of any of the affected villages. Traditional leaders have aligned themselves with either the JMC and the SDI Committee (Chief Mhlanga) or with the KMDF (the headman of Khanyayo village), but have generally not asserted an active leadership role for themselves. They have attempted to maintain their status as accepted local leaders, with a central role in land allocation, dispute resolution, etc., but have not been willing to risk losing support by attempting to take the lead in high-profile land struggles or arguments over the distribution of benefits from the SDI eco-tourism project. Ironically, SDI policy documents state that the SDI seeks to work with local leaders, who include traditional authorities as well as elected local government bodies [Mahlati, 2000]. These local leaders are supposed to act as 'community' representatives in SDI negotiations, as well as mediate in disputes.

But the SDI team, backed by both a powerful national government department and the provincial government, were willing to recognise another, more locally based 'representative' body in this role. The JMC (and later the Mkambati SDI Committee) received such recognition, despite having no statutory status and the absence of any formal guidelines as to what their decision-making powers were; nor were any mechanisms established to ensure transparency and accountability. Instead, the JMC instituted a strategy that was clearly designed to capture the SDI and its benefits. These included using mobile phones to contact government and SDI personnel to convey what they claimed were messages from 'local people', occupying empty buildings inside the Mkambati Nature Reserve, failing to announce community meetings when important visitors were coming and monopolising committee appointments.

The KMDF (sometimes acting in concert with the Khanyayo headman) has refused to acknowledge the authority of the JMC/SDI Committee. For them, powers such as the control of income flows from natural resources (for example, trees and river sand) clearly derive from ownership of the land and the resources on it.

\section{CONCLUSIONS}

The Mkambati case is one of contestation over land, natural resources and the spoils of development. Different actors have engaged in a diverse set of strategies and tactics aimed at increasing their power to further their own objectives, but none have articulated democratic decentralisation as a goal. 
The absence of a politics of democracy has been the key to stalling development in Mkambati. Central issues in democratic decentralisation are the establishment of downwardly accountable bodies that have appropriate powers and are composed of appropriate actors. As the Mkambati story shows, failure to explicitly address these issues can create opportunities for opportunists, resistance and intractable conflict, rather than concerted collective action in community-based development planning and natural resource management.

Another lesson from Mkambati relates to land and natural resources. Where these are central to people's livelihood strategies, and in particular where they are not held in private property regimes, the formal and informal institutional arrangements that mediate their use will deeply influence local decisions and actions in development initiatives such as the Wild Coast SDI. External agencies must understand these realities and make them central in development planning. Prospects for such 'realism' would be enhanced by building downwardly accountable institutions that take seriously the task of facilitating local participation in decision making.

On the evidence of this case, private-sector oriented forms of decentralised development planning can be highly problematic. An emphasis on external investment and 'community-private sector partnerships', without a clear role for representative decision-making bodies that are accountable to their constituencies, can easily lead to elite capture. Alternatively, as in Mkambati, local resistance to such capture can lead to disputes that stall investment and development. Functional and legitimate local institutional frameworks, together with the resolution of competing claims to land and resources, are preconditions for the success of partnerships such as those envisaged within the SDI.

The Mkambati case also suggests that the central state has an important role in facilitating democratic institutional development at the local level and in clarifying and supporting land and resource rights. Poorly planned and implemented programmes such as the Wild Coast SDI, with ineffective support from provincial and national government agencies, have hindered rather than assisted local processes and helped entrench intractable conflict. National programmes of tenure reform and land restitution have failed miserably in clarifying and securing local rights. Government actions have weakened rather than strengthened prospects for democratic governance as the local political and business elite have used their connections to provincial politicians to secure recognition of their committees, which are used as vehicles for personal accumulation. This suggests that effective government oversight of local processes is critical, and that 'even civil society depends on strong government' [Ribot, 2001: 20]. 


\section{NOTES}

1. In acknowledging that many eco-tourism projects in poor countries often do not benefit poor people, Ashley and Roe [2002] suggest that a conscious effort should be made to implement 'pro-poor tourism' strategies.

2. Controversy has erupted in relation to several features of the draft law. Critics have highlighted the following problems: the transfer of ownership of communal land from the state to communities and/or individuals will trigger massive boundary disputes and hinder service provision by municipalities; proposed levels of state support to local land administration bodies are inadequate; and giving chiefs a prescribed level of representation on land administration bodies will exacerbate tensions with local government [Cousins and Claassens, 2003].

3. A key informal institution is that of ukujola. This refers to illegal but locally legitimate forms of natural-resource use, such as hunting wildlife or gathering medicinal plants and other floral resources in the Mkambati Nature Reserve [Kepe, 1997].

4. The others were Dwesa/Cwebe/Nqabara, Coffee Bay/Hole-in-the-Wall, Port St Johns and Magwa.

\section{REFERENCES}

Ashley, C. and D. Roe, 2002, 'Making Tourism Work for the Poor: Strategies and Challenges in southern Africa', Development Southern Africa, Vol.19, No.1, pp.61-82.

Cousins, B. and A. Claassens, 2003, 'Communal Land Tenure in South Africa: Livelihoods, Rights and Institutions', Development Update, Vol.4, No.2, pp.55-77.

Department of Land Affairs, 1997, White Paper on Land Policy, Pretoria: Department of Land Affairs.

Government of Eastern Cape, 1998, 'Formal Invitation to Submit Pre-Qualification Proposals', Bisho: Ministry of Economic Affairs, Environment and Tourism.

Jourdan, P., 1998, 'Spatial Development Initiatives (SDIs) - The Official View', Development Southern Africa, Vol.15, No.5, pp.717-25.

Jourdan, P., K. Gordhan, D. Arkwright and G. de Beer, 1996, 'Spatial Development Initiatives (Development Corridors): Their Potential Contribution to Investment and Employment Creation', Unpublished paper.

Kepe, T., 2001, Waking up from the Dream: The Wild Coast SDI and the Pitfalls of 'Fast Track' Development, Research report No.8, Cape Town: Programme for Land and Agrarian Studies, School of Government, University of the Western Cape.

Kepe, T., 1999, "The Problem of Defining "Community": Challenges for the Land Reform Programme in Rural South Africa', Development Southern Africa, Vol.16, No.3, pp.415-33.

Kepe, T., 1997, Environmental Entitlements in Mkambati: Livelihoods, Social Institutions and Environmental Change on the Wild Coast of the Eastern Cape, Cape Town: Programme for Land and Agrarian Studies, University of the Western Cape.

Kepe, T., L. Ntsebeza and L. Pithers, 2001, 'Agro-Tourism Spatial Development Initiatives in South Africa. Are they Enhancing Rural Livelihoods?' Natural Resource Perspectives, No.65, Jan., London: Overseas Development Institute, pp.1-4.

Koch, E. with G. de Beer, S. Elliffe and others, 1998, 'SDIs, Tourism-led Growth and the Empowerment of Local Communities in South Africa', Development Southern Africa, Vol.15, No.5, pp.809-26.

Mahlati, V., 2000, 'Integrated Planning and Implementation in Rural Areas: Experiences from Agritourism Spatial Development Initiatives (SDIs)', in B. Cousins (ed.), At the Crossroads. Land and Agrarian Reform in South Africa into the 21st Century, Cape Town: Programme for Land and Agrarian Studies, School of Government, University of the Western Cape/Braamfontein, National Land Committee, pp.111-28.

Manor, J., 2000, 'Local Government in South Africa: Potential Disaster Despite Genuine Promise', Unpublished paper prepared for the United Kingdom's Department for International Development, Brighton: Institute for Development Studies, Sussex University.

Ntsebeza, L., 2001, 'Traditional Authorities and Rural Development in Post-Apartheid South Africa: The Case of the Transkei Region of the Eastern Cape', in J. Coetzee, J. Graaf, F. Hendricks and 
G. Woods (eds.), Development: Theory, Policy, and Practice, Cape Town: Oxford University Press.

Ntsebeza, L., 1999, Land Tenure Reform, Traditional Authorities and Rural Local Government in Post-Apartheid South Africa, Research Report No.3, Cape Town: Programme for Land and Agrarian Studies, School of Government, University of the Western Cape.

Platzky, L., 2000, 'Reconstructing and Developing South Africa: The Role of the Spatial Development Initiatives', Paper presented at the International Conference on Sustainable Regional Development, University of Massachusetts, Lowell, 28 Oct.

Ribot, J., 2001, 'Integral Local Development: "Accommodating Multiple Interests" through Entrustment and Accountable Representation', International Journal of Agricultural Resources, Governance and Ecology, Vol.1, No.3, pp.327-50.

Rogerson, C. and J. Crush, 2001, 'New Industrial Spaces: Evaluating South Africa's Spatial Development Initiatives (SDI) Programme', South African Geographical Journal, Vol.83, No.2, pp.85-92. 
Copyright of European Journal of Development Research is the property of Frank Cass \& Company Ltd. and its content may not be copied or emailed to multiple sites or posted to a listserv without the copyright holder's express written permission. However, users may print, download, or email articles for individual use. 